\title{
Využití vlastního hodnocení pro sledování kvality a rozvoje mateřské školy
}

\author{
The use of self - evaluation to monitor \\ the quality and the development of nursery school
}

Zora Syslová

\begin{abstract}
Abstrakt: Př́íspěvek se zabývá autoevaluačními procesy v mateřských školách, které jsou nahlíženy prostřednictvím jedné $\mathrm{z}$ pěti dimenzí. $\mathrm{V}$ empirické části příspěvek přibližuje závěry z dotazníkového šetření, kterého se zúčastnilo 290 respondentů z celé České republiky a rozhovorů se 17 předškolními pedagogy. Vývoj autoevaluačních procesů v mateřských školách napovídá, že se vzrůstajícími zkušenostmi roste jejich pozitivnější vnímání. Přesto stále přetrvává nesystematičnost a nedostatečná je také účelnost, s jakou se autoevaluace v mateřských školách provádí.
\end{abstract}

Klíčová slova: autoevaluace, dimenze, rozvoj školy

\begin{abstract}
The paper deals with self-evaluation processes in the kindergartens, which are viewed through the model of the five dimensions. In the empirical part, the contribution is approaching conclusion of the questionnaires, which was attended by 290 respondents from all over the Czech Republic and of the dialogues with 17 pre-primary educators. Progress of self-evaluation processes in the kindergartens suggests that with increasing experience is growing their positive perception. Still, there remains a lack of the systematicness and also the effectiveness which the self-evaluation in the kindergartens is worked with.
\end{abstract}

Keywords: self-evaluation, dimensions, school development

\section{1 Úvod}

Vlastní/interní hodnocení/evaluace je ve školách povinně realizováno již pátým rokem. Znamená to, že každá mateřská škola má za sebou alespoň dva autoevaluační procesy. Zákonnými dokumenty vymezujícími povinnost interní evaluace jsou zákon č. 561/2004 Sb., o předškolním, základním, středním, vyšším odborném a jiném vzdělávání, ve znění pozdějších předpisů (školský zákon), a jeho podzákonné normy, jakými jsou vyhláška č. 15/2005 Sb., kterou se stanoví náležitosti dlouhodobých záměrů, výročních zpráv a vlastního hodnocení školy a Rámcový vzdělávací program pro předškolní vzdělávání (RVP PV).

Pro označování procesů interní evaluace jsou v dosavadních zákonných dokumentech používány různé pojmy (vlastní hodnocení, autoevaluace) a odlišná je i jejich specifikace tohoto procesu (Prášilová \& Vašt'atková, 2006). Interní evaluaci si můžeme definovat (srov. Vašt'atková, 2009) jako systematické a plánované hodnocení na základě předem stanovených kritérií, které směřuje ke zkvalitnění práce školy a je prostředkem pro zavádění a řízení změn ve škole. 
Mnohem delší tradici má v českém prostředí externí evaluace, kterou vykonávala do roku 2004 pouze Česká školní inspekce (ČŠI). Se školským zákonem byla nově role externího hodnotitele přiznána také zřizovatelům škol. Existuje však řada dalších mechanismů či institucí, které se externím hodnocením zabývají, jde např. o komerční firmu Kalibro, je možné využít tzv. kritického prŕitele či benchmarkingové aktivity.

Externí a interní evaluace by neměly být samostatnými, oddělenými procesy, či si dokonce vzájemně odporovat. Ani jedna z obou typů evaluací v sobě nemá potenciál postihnout vzdělávací proces ve škole ve všech oblastech a jejich vzájemných vztazích. Mnoho autorů (Bečvářová, 2003; Pol, 2007; Vašt’atková, 2010) upozorňuje na to, že sice externí evaluace podporuje dobrou práci škol, ale sama o sobě k žádoucí kvalitě nepostačuje. K tomu by měla sloužit především evaluace vnitřní. Teprve vzájemná komplementarita dat získaných z obou typů evaluace může škole přinést ucelenější poznání o realitě školního života a $\mathrm{v}$ jeho důsledku také snahu tento stav měnit k lepšímu (srov. Havlínová et al., 2006).

\section{Východiska výzkumu}

Autorka využila pět dimenzí, které stanovila Vašt’atková (2010) a které charakterizují autoevaluační proces ve školách. Př́spěvek se podrobněji zabývá první z nich - dimenzi procesuálně-rozvojovou. Představuje autoevaluaci jako proces, který podněcuje proměnu školy. Znamená to, že nejde jen o pouhou deskripci fungování školy, ale zjištěné informace vedou k následným akcím směřujícím ke zkvalitnění práce školy. První dimenze se primárně týká vlivu autoevaluace na rozvoj školy. Na rozdíl od ostatních čtyř představuje především naplňování požadavků školského zákona a dalších zákonných norem.

Dalšími dimenzemi jsou dimenze profesně-administrativní (autoevaluační procesy vyžadují specifické znalosti a dovednosti aktérů těchto procesů, které jim umožní efektivně využívat zjištěné údaje, aplikovat různé postupy pro zpracovávání a interpretaci dat), dimenze komunikačně-kolektivní (autoevaluace školy není záležitostí jednotlivců, jde při ní o průběžnou komunikaci, vysvětlování, vyjednávání, sdílení a šíření informací mezi jednotlivými aktéry), dimenze kulturně-etická (autoevaluace pomáhá škole poznávat své hodnoty, svoji kulturu a pěstovat je dál) a poslední je vztahově-kontextová dimenze (jde při ní o prrijetí vlivu externí evaluace na interní).

\section{Cíle výzkumu, jeho metodologie}

Cílem výzkumného šetření bylo zjistit, zda mateřské školy využívají vlastní hodnocení k rozvoji a zkvalitnění předškolního vzdělávání. Při zkoumání autoevaluačních procesů v mateřských školách bylo využito různých zdrojů informací získaných prostřednictvím následujících výzkumných šetření:

a) Výsledky dotazníkového šetření, které proběhlo počátkem roku 2011.

b) Výsledky rozhovorů s předškolními pedagogy konaných v rámci disertační práce v roce 2009 (Syslová, 2010).

Základní metodou bylo dotazníkové šetření. Po dohodě s autorkou dotazníku (Vašt’aková, 2010) byl upraven pro potřeby mateřských škol a rozeslán do krajských školicích střredisek s prosbou o distribuci do mateřských škol. V průvodním dopise byl odkaz na webové rozhraní (http://www.ped.muni.cz/wprimped/vyzkum2010). Dotazník byl přepsán do jazyka PHP tak, aby se data při odeslání vyplněného dotazníku mohla kódovat a ukládat do databáze MySQL. 
Dotazník obsahoval 27 položek, ve kterých se objevily jak otevřené otázky, tak otázky s výběrem z nabízených hodnotících polí. Součástí dotazníku byly identifikační údaje o druhu a velikosti školy, kraje, velikosti obce, funkci ve škole a době praxe ve školství.

V první fázi byla data nejprve analyzována deskriptivními a statistickými postupy. Ve druhé fázi zpracování dat byl proveden Pearsnův chí-kvadrát test nezávislosti.

Individuální polostrukturovaný rozhovor poskytlo 17 předškolních pedagogů z Jihomoravského kraje. Rozhovory probíhaly v jednotlivých mateřských školách, v počtu šesti. Doba trvání rozhovoru se pohybovala v rozmezí 20-30 minut. Rozhovory byly nahrávány na digitální diktafon a poté byly přepsány a analyzovány podle paradigmatu zakotvené teorie otevřeným kódováním. Analýza odpovědí z polostrukturovaného rozhovoru zahrnuje kvalitativní (obsahovou analýzu) a kvantitativní deskripci četností odpovědí. Výroky, které spadaly do některé z kategorií, byly zaznamenané 1 = vyskytlo se. 0 znamená nevyskytlo se.

\section{Závěry výzkumu}

\subsection{Výsledky dotaznikového šetření}

Dotazník vyplnilo 290 respondentů z celé České republiky. Respondenti byli z 69 \% ředitelé škol, $21 \%$ tvořili zástupci ředitelů nebo vedoucí předškolního vzdělávání a zbývající část $10 \%$ tvořili učitelé. V $91 \%$ respondenti uvedli, že mají deseti- a víceletou pedagogickou praxi.

Dotazníkové šetření přineslo zjištění, že neoblíbenost autoevaluace statisticky významně souvisí s tím, že není vnímán její vliv na zvyšování kvality školy. Téměř 30 \% odpovídajících se domnívá, že autoevaluace nepřináší nové poznatky a potvrzuje známé. Ve školách, kde je autoevaluace vnímána jako velmi užitečná, zkvalitňuje výuku. Tam, kde je autoevaluace vnímána jako neužitečná, rozhodně podle respondentů výuku nezkvalitňuje. Ve školách, kde je autoevaluace vnímána jako velmi užitečná, platí, že autoevaluace přináší nové poznatky. (Analogicky můžeme vyvodit, že ve školách, kde je autoevaluace vnímána jako neužitečná, potvrzuje aktérům známé a nepřináši jim nové poznatky.) $9 \%$ respondentů pak považuje autoevaluaci za zbytečnou (práci navíc), nebot' nepřináší žádné informace, ani neposouvá kvalitu školy. Dvě třetiny respondentů uvedly, že výsledky autoevaluace využívají k dalšímu plánování, ale pouze $44 \%$ připouští, že přináší posuny v práci.

Z výpovědí respondentů $\mathrm{k}$ otázce spokojenosti s činností ČŠI v posledních dvou letech vyplývá, že vzrůstá pozitivní postoj k hodnocení ČŠI (srov. Syslová, 2009). Lze se však domnívat, že tento postoj je velmi ovlivněn výsledky externího hodnotitele. V prŕípadě, že inspekce byla vstřícná, inspektorky „radily“ a hodnocení bylo pozitivní, byla spokojená i škola. Často však zaznívala nespokojenost a kritika práce Č ̌̌I, např.: „Spokojeni jsme nebyli, p. inspektorka nechtěla slyšet náš názor, vedla si svou.“"

Postoje učitelů k vlastnímu hodnocení můžeme sledovat také v kontextu některých dalších odpovědí. $56 \%$ respondentů uvedlo, že jim vlastní hodnocení nepřináší žádné efekty. $\mathrm{V}$ posledních dvou letech však 68 \% z nich absolvovalo školení k vlastnímu hodnocení a 71 $\%$ je hodnotí pozitivně. Pomoc by ale potřebovalo $56 \%$ respondentů.

\subsection{Výsledky individuálních rozhovorů}

Pro potřeby tohoto výzkumného šetření bylo využito pouze dvou otázek $\mathrm{z}$ individuálního rozhovoru. První otázkou bylo, Co vás napadá, když se řekne vlastní hodnoceni mateřské školy? K nejčastějším odpovědím patřilo, že „to je hodnocení naší práce o tom, jak s dětmi 
pracujeme, jaké máme výsledky, a o tom co nás posiluje dál $\mathrm{z}$ těch výsledků, abychom se mohli odrazit dál a odvíjet od toho další plánování“ (respondentka 10).

Pouze jednou byla zmíněna spojitost se zákonným požadavkem - „hodnocení práce celkově, ze zákona, jednou za 3 roky“ (respondentka 16). Několikrát se mezi odpověd'mi objevila asociace s používanými metodami a nástroji při vlastním hodnocení mateřské školy, např. „hospitace, evaluace, diagnostika dětí, pak hodnocení mezi učitelkami navzájem nebo takové to koukání se, pak vlastně celkově za ten rok, co se podařilo, akce jestli budeme znovu něco opakovat..."(respondentka 3 ).

Druhou otázkou bylo, Jak používáte (k čemu využíváte) výsledky z vlastního hodnocení? Při kódování odpovědí byly vytvořeny 3 kategorie (viz tabulka 1), jejichž výskyt v odpovědích jednotlivých respondentek byl zaznamenán do tabulky.

Tabulka 1

Využití výsledků sebehodnocení učitelek a hospitací ředitelky

\begin{tabular}{|l|l|l|l|l|l|l|l|l|l|l|l|l|l|l|l|l|l|l|}
\hline $\begin{array}{l}\text { KATEGORIE - } \\
\text { využití výsledků }\end{array}$ & $\mathbf{1}$ & $\mathbf{2}$ & $\mathbf{3}$ & $\mathbf{4}$ & $\mathbf{5}$ & $\mathbf{6}$ & $\mathbf{7}$ & $\mathbf{8}$ & $\mathbf{9}$ & $\mathbf{1 0}$ & $\mathbf{1 1}$ & $\mathbf{1 2}$ & $\mathbf{1 3}$ & $\mathbf{1 4}$ & $\mathbf{1 5}$ & $\mathbf{1 6}$ & $\mathbf{1 7}$ & Četnost \\
\hline $\begin{array}{l}\text { Změna práce } \\
\text { (rozvoj) }\end{array}$ & 1 & 0 & 1 & 0 & 1 & 0 & 1 & 1 & 1 & 1 & 1 & 1 & 1 & 1 & 1 & 1 & 1 & $\mathbf{1 3}$ \\
\hline $\begin{array}{l}\text { Zpracování } \\
\text { dokumentů }\end{array}$ & 1 & 0 & 0 & 1 & 0 & 1 & 1 & 0 & 0 & 0 & 0 & 1 & 1 & 0 & 0 & 0 & 1 & $\mathbf{7}$ \\
\hline Pozitivní motivace & 0 & 0 & 0 & 0 & 0 & 0 & 0 & 0 & 0 & 0 & 0 & 0 & 0 & 1 & 1 & 0 & 0 & $\mathbf{2}$ \\
\hline
\end{tabular}

\section{Diskuse, závěrečné shrnutí}

Výsledky přinesly řadu pozitivních informací, přesto ukazují na přetrvávající problémy v hodnotících procesech mateřských škol. Nedostatečné je především jejich využití pro zavádění změn a zkvalitňování vzdělávací práce. Tyto informace jsou v souladu s výsledky některých dalších výzkumných šetření (Pol, 2007; Šlajchová, 2007).

Také zprávy ČŠI přinášejí informace o spíše formálních přístupech škol k vlastnímu hodnocení a o tom, že školy nedokáží pracovat s výsledky vlastního hodnocení:

...nedostatečné nastavení vlastního hodnocení se projevilo v 51,9 \% MŠ. Tato oblast často neodpovídá požadavkům školského zákona a platné vyhlášky, školy neumí nastavit odpovědnost PP za vlastní hodnocení. Velmi častý je pouze formální a nefunkční popis, jednotlivé části nevytvářejí ucelený systém (40,5 \% MŠ), neobsahují časové plány, způsoby hodnocení. Pravidla pro systematické hodnocení výsledků vzdělávání dětí a jejich pokroku nejsou v ŠVP správně nastavena. (ČŠI, 2010, s. 7)

Zčásti může být vysvětlení problémů mateřských škol s vlastním hodnocením v nízké podpoře státu. Bylo sice připraveno několik podpůrných aktivit (metodická příručka VÚP Autoevaluace mateřské školy, 2008; DVPP Autoevaluace mateřských škol, NIDV), ale ve světle výsledků dotazníkového šetření se tato podpora jeví jako nedostačující.

Existuje také několik regionálních projektů na podporu autoevaluace škol (např. MEC Ostrava), ale v podstatě jde o ojedinělé aktivity, které postrádají systémovost s celonárodní působností. Jediným projektem s celonárodní působností je projekt Cesta ke kvalitě. Prioritně se však tento projekt věnuje autoevaluaci v primárním a sekundárním vzdělávání. Pouze některé $\mathrm{z}$ autoevaluačních nástrojů bude možné využít také v mateřských školách.

Pro to, aby mateřské školy dosahovaly lepších výsledků a opustily formální př́ístup, bude nutná mnohem větši podpora ze strany státu, než jaké se jim dostalo doposud. 


\section{Literatura}

Bečvářová, Z. (2003). Současná mateřská škola a její ř́zení. Praha: Portál.

Havlínová, M., \& Vencálková, E. (Eds.). (2006) Kurikulum podpory zdraví v mateřské škole (aktualizovaný program). Praha: Portál.

Pol, M. (2007). Škola v proměnách. Brno: MU v Brně.

Průcha, J., Walterová, E., \& Mareš, J. (2008). Pedagogický slovník. Praha: Portál.

Prášilová, M., \& Vašt’atková, J. (2006). Současné pohledy na procesy vnitřní evaluace škol v českém prostředí. Pedagogika, 56(3), 273-284

Smolíková, K., et al. (2008). Autoevaluace mateřské školy. Metodická přiručka k vlastnímu hodnocení. Praha: VÚP v Praze.

Syslová, Z. (2010). Proces vlastního hodnoceni mateřských škol. (Bakalářská práce). Praha: PdF UK v Praze.

Syslová, Z. (2010). Průběh vzdělávání jako jedna z oblastí vlastního hodnocení mateřské školy. (Disertační práce.) Praha: PdF UK v Praze.

Starý, K., \& Shánilová, I. (2010). Koordinátor autoevaluace. Praha: Národní institut pro další vzdělávání.

Straková, J. et al. (2009). Analýza naplnění cílů Národního programu rozvoje vzdělávání v České republice (Bílé knihy) v oblasti predškolniho, základního a středního vzdělávání. Dostupné z http://www.msmt.cz/vzdelavani/skolskareforma/analyza-naplnovani-cilu-vzdelavani.

Šlajchová, L. (2007). Autoevaluace v praxi základnich škol. (Disertační práce). Praha: UK v Praze.

Tematická zpráva ČŠI. (2010). Inspekčni hodnoceni školnich vzdělávacich programů za období 2007/2010. Praha: ČŠI. Dostupné z http://www.csicr.cz.

Vašt’atková, J. (2009) Autoevaluace škol. In J. Průcha (Ed.), Pedagogická encyklopedie (pp. 582586). Praha: Portál.

Vašt’atková, J. (2010). Autoevaluace a benchmarking ve škole. Olomouc: Hanex.

\section{Kontakt}

PhDr. Zora Syslová, Ph.D.

Masarykova univerzita

Pedagogická fakulta, Katedra primární pedagogiky

Poříčí 7, 60300 Brno

e-mail: syslova@ped.muni.cz

\section{Bibliografické údaje}

Syslová, Z. (2011). Využití vlastního hodnocení pro sledování kvality a rozvoje mateřské školy. In T. Janík, P. Knecht, \& S. Šebestová (Eds.), Smíšený design v pedagogickém výzkumu: Sborník př́spěvků z 19. výroční konference České asociace pedagogického výzkumu (s. 378-382). Brno: Masarykova univerzita.

Dostupné z: http://www.ped.muni.cz/capv2011/sbornikprispevku/syslova.pdf

doi: 10.5817/PdF.P210-CAPV-2012-77 